\title{
Pengaruh Perendaman Ekstrak Bunga Sepatu (Hibiscus rosa sinensis L.) terhadap Pertumbuhan Candida albicans pada Plat Resin Akrilik
}

\author{
Yuhi Syaula, ${ }^{1}$ Arlita L. Antari, ${ }^{2}$ Diah A. Purbaningrum ${ }^{1}$
}

\author{
${ }^{1}$ Departemen Kedokteran Gigi Fakultas Kedokteran Universitas Diponegoro, Semarang, \\ Indonesia \\ ${ }^{2}$ Departemen Ilmu Mikrobiologi Fakultas Kedokteran Universitas Diponegoro, Semarang, \\ Indonesia \\ Email: yuhisyaula@gmail.com; arlitaleniseptariaantari@yahoo.com; \\ diahajeng88@gmail.com
}

\begin{abstract}
Denture plate materials such as acrylic resin can induce adhesion of Candida albicans. Therefore, acrylic resin needs to be immersed in disinfectant. However, disinfectant can change its physical and mechanical properties, hence an alternative material is needed, such as hibiscus flower (Hibiscus rosa sinensis L.) due to its antifungal activity. This study was aimed to identify the effects of hibiscus flower extract and its concentrations towards the growth of $C$. albicans on acrylic resin plates. This was an experimental and laboratory study using the post-test only with control group design. Acrylic resins were immersed in suspension of $C$. albicans, then were divided into four groups, as follows: $62.5 \%$ and $75 \%$ hibiscus flower extract (group I and II), positive control (sodium hypochlorite), and negative control (sterile aquadest). Acrylic resins were cultured and incubated on SDA media for 24 hours then the number of colonies were calculated. The results showed that $C$. albicans colonies in the treatment groups I, II, negative control, and positive control were $495 \mathrm{CFU} / \mathrm{ml}, 571.25 \mathrm{CFU} / \mathrm{mL}, 1175 \mathrm{CFU} / \mathrm{mL}, 23.125 \mathrm{CFU} / \mathrm{mL}$ respectively. The Kruskal-Wallis test showed significant differences in number of colonies of $C$. albicans $(\mathrm{p}<0.05)$ among all groups The post hoc Mann-Whitney test showed that all groups were significantly different, except for treatment groups I towards II. In conclusion, extract of hibiscus flower ( $H$. rosa sinensis $L$.) affected the growth of $C$. albicans on acrylic resin plates.
\end{abstract}

Keywords: hibiscus flower; Hibiscus rosa sinensis L.; Candida albicans; acrylic resin

\begin{abstract}
Abstrak: Adanya bahan plat basis gigi tiruan seperti resin akrilik dapat memicu perlekatan $C$. albicans; oleh karena itu, resin akrilik perlu direndam dalam larutan desinfektan. Namun, larutan desinfektan dapat mengubah sifat fisik dan mekanik dari akrilik sehingga diperlukan adanya bahan alternatif, antara lain bunga sepatu (Hibiscus rosa sinensis L.) yang memiliki aktivitas antifungal. Penelitian ini bertujuan untuk mengetahui pengaruh perendaman ekstrak dan konsentrasi bunga sepatu terhadap pertumbuhan $C$. albicans pada plat resin akrilik. Jenis penelitian ialah eksperimental laboratorik dengan post-test only with control group design. Resin akrilik direndam dalam suspensi $C$. albicans, Terdapat empat kelompok perlakuan yaitu ekstrak bunga sepatu $62,5 \%$ dan $75 \%$, kontrol positif (sodium hipoklorit), dan kontrol negatif (akuades steril). Resin akrilik dikultur dan diinkubasi pada media SDA selama 24 jam, kemudian jumlah koloni $C$. albicans dihitung. Hasil penelitian ini menunjukkan jumlah koloni $C$. albicans kelompok perlakuan I, II, kontrol negatif, dan positif sebanyak $495 \mathrm{CFU} / \mathrm{ml}, 571.25 \mathrm{CFU} / \mathrm{mL}, 1175$ $\mathrm{CFU} / \mathrm{mL}, 23.125 \mathrm{CFU} / \mathrm{mL}$ secara berurut. Uji Kruskal-Wallis menunjukkan perbedaan jumlah koloni $C$. albicans yang bermakna $(\mathrm{p}<0.05)$ antar semua kelompok. Uji post hoc Mann-Whitney menunjukkan semua kelompok berbeda bermakna, kecuali kelompok perlakuan I dengan II. Simpulan penelitian ini ialah ekstrak bunga sepatu (H. rosa sinensis $L$.) berpengaruh terhadap pertumbuhan C. albicans pada plat resin akrilik.
\end{abstract}

Kata kunci: bunga sepatu; Hibiscus rosa sinensis L.; Candida albicans; resin akrilik 


\section{PENDAHULUAN}

Masalah kesehatan gigi yang cukup serius yaitu kehilangan gigi, banyak ditemukan di masyarakat. Keadaan ini dapat mengganggu fungsi pengunyahan, fungsi bicara, dan estetika, serta memengaruhi kualitas hidup seseorang. ${ }^{1}$ Prevalensi kehilangan gigi di Indonesia pada usia $\geq 12$ tahun sebesar $1,3 \%$ dan pada usia $\geq 65$ tahun sebesar $9,0 \% .^{2}$ Masalah kehilangan gigi ini dapat diatasi dengan pembuatan gigi tiruan.

Gigi tiruan merupakan protesa yang menggantikan gigi yang hilang sebagian atau seluruhnya beserta jaringan sekitarnya. Pembuatan gigi tiruan mempunyai tujuan untuk memperbaiki estetika penampilan dan kenyamanan, mengembalikan fungsi mastikasi dan fonetik, serta melindungi jaringan pendukung yang berada di bawah gigi tiruan. ${ }^{3,4}$ Salah satu komponen gigi tiruan yaitu plat basis. ${ }^{5,6}$ Bahan dari plat basis gigi tiruan yang sering dipakai saat ini yaitu resin akrilik. ${ }^{7}$ Resin akrilik masih menjadi bahan pilihan dalam pembuatan basis gigi tiruan karena tidak bersifat toksik, tidak mengiritasi jaringan, mempunyai sifat fisik dan estetika yang baik, harganya relatif murah, mudah dimanipulasi dan direparasi, stabilitas dimensi baik, serta alat yang digunakan sederhana. $^{8-11}$

Penggunaan basis gigi tiruan dengan resin akrilik memiliki kekurangan yaitu terdapat rongga-rongga mikro yang dapat menjadi tempat penumpukan sisa makanan. ${ }^{11}$ Sisa makanan dan deposit mengandung mikroorganisme yang melekat pada permukaan gigi tiruan disebut denture plaque. ${ }^{12}$ Mikroorganisme yang melekat dapat menyebabkan inflamasi pada mukosa yang berlanjut sebagai denture stomatitis, yaitu suatu reaksi inflamasi berbentuk lesi yang terjadi pada jaringan lunak penyangga gigi tiruan di dalam rongga mulut. ${ }^{13}$

Denture stomatitis diakibatkan oleh beberapa jenis mikroorganisme, salah satunya yang berperan dengan prevalensi tertinggi (86\%) yaitu Candida albicans. ${ }^{13,14} C$. albicans merupakan flora normal dalam rongga mulut namun dapat menjadi jamur patogen bila terdapat faktor predisposisi seperti penyakit sistemik yang kronis, kebiasaan merokok, kesehatan mulut kurang baik, dan memakai gigi tiruan yang kurang baik. Kondisi ini menyebabkan ketidakseimbangan pertumbuhan flora normal dalam rongga mulut, sehingga $C$. albicans tumbuh lebih banyak dan dapat menyebabkan infeksi oportunistik bila mengalami pertumbuhan yang berlebih. ${ }^{15}$ Upaya agar gigi tiruan tidak menjadi tempat perlekatan berkembangnya $C$. albicans yaitu dengan perawatan kebersihan gigi tiruan. ${ }^{6}$ Perawatan kebersihan gigi tiruan juga diperlukan guna mencegah atau menghilangkan sisasisa makanan, akumulasi mikroorganisme, serta perubahan warna. Salah satu cara yang dapat dilakukan yaitu secara kimiawi dengan merendam pada larutan disinfektan, alkali peroksida, atau alkali hipoklorit. ${ }^{16}$ Bahan-bahan pembersih gigi tiruan yang beredar saat ini harganya relatif mahal dan memiliki kadar toksisitas rendah. Beberapa bahan pembersih gigi tiruan yang digunakan seringkali dapat mengubah sifat fisik dan mekanik dari resin saat perendaman yaitu perubahan dimensi dan perubahan warna sehingga diperlukan adanya bahan alternatif sebagai pengganti bahan pembersih gigi tiruan yang relatif lebih murah, tidak menyebabkan perubahan dimensi dan warna, serta tidak bersifat toksik. ${ }^{6,17}$

Salah satu tanaman yang dapat dimanfaatkan di Indonesia sebagai bahan alternatif pembersih gigi tiruan yaitu bunga sepatu (Hibiscus rosa sinensis L.). ${ }^{18}$ Di Indonesia tanaman bunga sepatu (H. rosa sinensis $L$.) merupakan tanaman yang mudah ditemukan di pekarangan, bermanfaat sebagai pagar hidup, bahan pangan olahan seperti sayur, salad, pewarna makanan, serta sebagai penyubur rambut. Berdasarkan hasil uji analisis fitokimia, bunga sepatu ( $H$. rosa sinensis L.) memiliki kandungan senyawa kimia seperti flavonoid, polifenol, tanin, saponin, alkaloid, minyak atsiri yang berguna dalam pengobatan dengan memiliki berbagai macam bioaktivitas antara lain antiinflamasi, antikanker, antifertilitas, antiviral, antidiabetes, antidepresan, diuretik, serta antifungal. ${ }^{18-21}$

Cyanidin dan quercetin merupakan salah satu dari grup anthocyanin dan 
flavonoid yang mempunyai konsentrasi paling banyak pada bagian bunga tanaman bunga sepatu. Cyanidin dan quercetin tersebut memiliki aktivitas antifungal yang cukup bermakna terhadap berbagai fungi patogen karena mampu menghambat spora patogen, dan digunakan sebagai pengobatan jamur patogen. ${ }^{19,22}$ Penelitian sebelumnya oleh Krista dan Arundina ${ }^{22}$ menunjukkan bahwa ekstrak bunga sepatu (H. rosa sinensis L.) dengan konsentrasi hambat minimal (KHM) sebesar $62,5 \%$ mampu menghambat pertumbuhan koloni $C$. albicans setelah diuji pada beberapa konsentrasi. ${ }^{22}$

Berdasarkan latar belakang yang telah diuraikan, maka penulis merasa perlu untuk melakukan penelitian guna mengetahui pengaruh perendaman ekstrak bunga sepatu (H. rosa sinensis $L$.) terhadap pertumbuhan koloni $C$. albicans pada plat gigi tiruan resin akrilik.

\section{METODE PENELITIAN}

Jenis penelitian ini ialah eksperimental laboratorik dengan post-test only with control group design. Sampel yang digunakan ialah resin akrilik heat cured yang memenuhi kriteria inklusi dan eksklusi. Kriteria inklusi penelitian ini ialah sampel berupa plat resin akrilik heat cured berukuran $10 \mathrm{~mm} \times 10 \mathrm{~mm}$, tebal $2 \mathrm{~mm}$, memiliki bentuk dan ukuran yang seragam, serta resin akrilik yang dilakukan polishing pada dua permukaan. Kriteria eksklusi ialah sampel resin akrilik yang terdapat porus/ gelembung dan resin akrilik yang tidak dipoles dua permukaan. Variabel bebas dari penelitian ini ialah ekstrak bunga sepatu $(H$. rosa sinensis L.) konsentrasi $62,5 \%$ dan $75 \%$ sedangkan variabel terikat ialah pertumbuhan $C$. albicans pada plat gigi tiruan resin akrilik.

Pembuatan sampel dilakukan dengan pembuatan cetakan/mould, packing resin akrilik heat cured, pemanasan resin akrilik heat cured (curing), dan pemolesan resin akrilik (polishing).

Pembuatan ekstrak bunga sepatu dilakukan sebagai berikut: bunga sepatu (Gambar 1) dikeringkan dengan air suling lalu dikeringkan dengan diangin-anginkan tanpa terkena sinar matahari secara langsung, kemudian dilakukan homogenisasi dengan cara ditumbuk halus. Setiap 25 gram bubuk bunga yang telah dikeringkan ditempatkan dalam $100 \mathrm{ml}$ metanol. Penyimpanan dilakukan dalam rotary shaker pada 190-220 rpm selama 24 jam. Material tanaman diendapkan selama 5 jam, kemudian hasil disaring dan disentrifugasi pada kecepatan 5000 rpm selama 15 menit, supernatan diambil dan pelarut diuapkan pada suhu $45^{\circ} \mathrm{C}$ dalam vacuum evapourator hingga didapatkan ekstrak murni tanpa pelarut. Pencampuran ekstrak murni dengan pelarut menyesuaikan konsentrasi yang diteliti yaitu $62,5 \%$ dan $75 \%$.

Pembuatan suspensi $C$. albicans dilakukan dengan cara melarutkan isolat jamur C. albicans kedalam $10 \mathrm{ml}$ media BHI, kemudian diinkubasi selama 8 jam pada suhu $37^{\circ} \mathrm{C}$, sehingga diperoleh suspensi jamur. Penelitian dilakukan dengan perendaman sampel resin akrilik heat cured dalam aquadest steril selama 48 jam, lalu dilakukan sterilisasi dengan autoklaf $121^{\circ} \mathrm{C}$ selama 18 menit, sampel direndam larutan PBS (phosphate buffer saline) selama \pm 1 jam.

Resin akrilik direndam dalam $10 \mathrm{ml}$ suspensi $C$. albicans selama 24 jam pada suhu $37^{\circ} \mathrm{C}$ dalam tabung reaksi disesuaikan dengan standar McFarland. Sebanyak empat kelompok resin akrilik dimasukkan dalam ekstrak bunga sepatu $62,5 \%$ dan $75 \%$, kontrol positif (sodium hipoklorit), dan kontrol negatif (akuades steril), direndam selama 8 jam. Resin akrilik dibilas dengan larutan PBS dan dimasukkan ke dalam tabung reaksi, lalu dilakukan vibrasi selama 30 detik pada tabung reaksi. Kemudian resin akrilik diusap kedalam media SDA steril serta diinkubasi selama 24 jam. Perhitungan koloni $C$. albicans dengan colony counter dalam satuan CFU/ml.

Data berupa jumlah koloni $C$. albicans pada masing-masing kelompok dilakukan uji normalitas dan homogenitas menggunakan uji Shaphiro Wilk dan uji Levenne. Jika data terdistribusi normal maka dilanjutkan dengan uji One Way ANOVA, dan post hoc test menggunakan uji Least Significant 
Difference ( $L S D)$. Namun bila data tidak terdistribusi normal, maka digunakan analisis data non parametrik dengan uji Kruskal Wallis yang dilanjutkan dengan uji Mann Whitney.

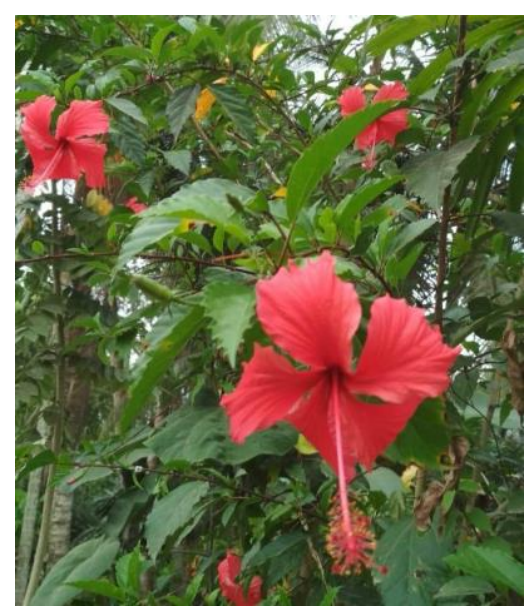

Gambar 1. Bunga kembang sepatu (Hibiscus rosa sinensis $L$.), lokasi di Semarang

\section{HASIL PENELITIAN}

Setelah dilakukan perhitungan jumlah koloni $C$. albicans pada semua kelompok dilakukan analisis deskriptif seperti yang disajikan pada Tabel 1.

Hasil perhitungan tersebut kemudian dilakukan uji normalitas menggunakan uji Shapiro Wilk dan didapatkan nilai $p$ kelompok perlakuan I 0,538 , perlakuan II 0,460, kontrol negatif 0,031, dan kontrol positif 0,007. Kemudian dilakukan uji homogenitas Levene yang mendapatkan nilai 0,000 , yang menunjukkan bahwa data terdistribusi tidak normal, sehingga dapat disimpulkan hasil eksperimen terdistribusi tidak normal. Oleh karena itu, pengolahan data dilanjutkan dengan menggunakan uji non-parametrik Kruskal-Wallis yang diperlihatkan pada Tabel 2.

Berdasarkan hasil uji Kruskal-Wallis, rerata jumlah koloni $C$. albicans pada seluruh kelompok memiliki hasil yang bermakna dan diperlukan uji lanjutan menggunakan uji post hoc dengan uji MannWhitney untuk menganalisis perbedaan antara masing-masing kelompok perlakuan seperti yang disajikan pada Tabel 3 .

Tabel 1. Hasil analisis deskriptif

\begin{tabular}{lc}
\hline Kelompok & $\begin{array}{c}\text { Mean } \pm \text { SD } \\
(\text { CFU/ml) }\end{array}$ \\
\hline $\begin{array}{l}\text { Perlakuan I (ekstrak } \\
\text { bunga sepatu 75\%) }\end{array}$ & $495 \pm 58,6$ \\
$\begin{array}{l}\text { Perlakuan II (ekstrak } \\
\text { bunga sepatu 62,5\%) }\end{array}$ & $571,25 \pm 74,8$ \\
$\begin{array}{l}\text { Kontrol negatif } \\
\text { (akuades steril) }\end{array}$ & $1175 \pm 146$ \\
$\begin{array}{l}\text { Kontrol positif } \\
\text { (sodium hipoklorit) }\end{array}$ & $23,125 \pm 12,4$ \\
\hline
\end{tabular}

Tabel 2. Hasil uji Kruskal-Wallis

\begin{tabular}{llcc}
\hline \multicolumn{1}{c}{ Kelompok } & Mean Rank & Nilai p \\
\hline Jumlah koloni & Ekstrak bunga sepatu 75\% & 16,06 & \\
& Ekstrak bunga sepatu 62,5\% & 17,63 & \multirow{2}{*}{$0,000^{*}$} \\
& Akuades steril & 27,81 & \\
& Sodium hipoklorit & 4,50 & \\
\hline
\end{tabular}

*Bermakna bila: $\mathrm{p}<0,05$

Tabel 3. Hasil uji Mann-Whitney antar kelompok perlakuan

\begin{tabular}{ccccc}
\hline Kelompok & $\mathbf{P 1}$ & $\mathbf{P 2}$ & $\mathbf{K}(-)$ & $\mathbf{K}(+)$ \\
\hline P1 & - & 0,562 & $0,001^{*}$ & $0,001^{*}$ \\
$\mathbf{P 2}$ & 0,562 & - & $0,003^{*}$ & $0,001^{*}$ \\
$\mathbf{K}(-)$ & $0,001^{*}$ & $0,003^{*}$ & - & $0,001^{*}$ \\
$\mathbf{K}(+)$ & $0,001^{*}$ & $0,001^{*}$ & $0.001^{*}$ & - \\
\hline
\end{tabular}

*Bermakna bila: $\mathrm{p}<0,05$ 
Berdasarkan uji beda Mann-Whitney, kelompok perlakuan I (ekstrak bunga sepatu $75 \%$ ) dengan kelompok perlakuan II (ekstrak bunga sepatu 62,5\%) menunjukkan hasil $p>0,05$ yang berarti tidak terdapat perbedaan bermakna. Kelompok perlakuan I (ekstrak bunga sepatu 75\%) dengan kelompok kontrol negatif menunjukkan hasil $\mathrm{p}<0,05$ yang berarti terdapat perbedaan bermakna.

Kelompok perlakuan I (ekstrak bunga sepatu 75\%) dengan kelompok kontrol positif menunjukkan hasil $\mathrm{p}<0,05$ yang berarti terdapat perbedaan bermakna. Kelompok perlakuan II (ekstrak bunga sepatu 62,5\%) dengan kelompok kontrol negatif menunjukkan hasil $\mathrm{p}<0,05$ yang berarti terdapat perbedaan bermakna. Kelompok perlakuan II (ekstrak bunga sepatu 62,5\%) dengan kelompok kontrol positif menunjukkan hasil $\mathrm{p}<0,05$ yang berarti terdapat perbedaan bermakna, sedangkan kelompok kontrol negatif dengan kelompok kontrol positif menunjukkan hasil $\mathrm{p}<0,05$ yang berarti terdapat perbedaan bermakna.

\section{BAHASAN}

Berdasarkan hasil penelitian, didapatkan bahwa rerata jumlah koloni kelompok kontrol negatif lebih tinggi dibanding kelompok perlakuan, dengan urutan terbesar yaitu kelompok kontrol negatif (rerata $1175 \mathrm{CFU} / \mathrm{ml}$ ); kelompok P2 ekstrak bunga sepatu 62,5\% (rerata 571,25 CFU/ml); kelompok P1 ekstrak bunga sepatu $75 \%$ (rerata $495 \mathrm{CFU} / \mathrm{ml}$ ); dan kelompok kontrol positif (rerata 23,125 $\mathrm{CFU} / \mathrm{ml}$ ). Hal ini sejalan dengan penelitian yang dilakukan oleh Mozartha et $\mathrm{al}^{23}$ yang menyatakan bahwa kelompok kontrol negatif berupa akuades steril memiliki jumlah rerata koloni C. albicans paling banyak dibandingkan kelompok perlakuan yang diberikan ekstrak bunga sepatu dan kelompok kontrol positif. Hal ini disebabkan karena tidak adanya zat aktif anti jamur yang terkandung dalam akuades tersebut.

Perbedaan rerata selanjutnya dianalisis menggunakan uji Kruskal-Wallis dan diperoleh nilai $p=0,000(p<0,05)$ yang berarti terdapat perbedaan bermakna antara rerata masing-masing kelompok. Hasil yang tidak normal dan tidak homogen pada data diduga disebabkan oleh perbedaan rerata jumlah koloni C. albicans pada masing-masing kelompok. Perbandingan rerata jumlah koloni pada kontrol negatif dan kontrol positif memiliki perbedaan yang terpaut jauh. Hal ini diduga disebabkan oleh pemolesan sampel resin akrilik secara manual menggunakan amplas (nomor 1000) sehingga kehalusan permukaan masing-masing sampel tidak merata. ${ }^{23}$ Jumlah koloni $C$. albicans pada permukaan resin akrilik yang kasar cenderung lebih banyak dibandingkan permukaan resin akrilik yang halus. ${ }^{24}$ Kekasaran permukaan resin akrilik dapat disebabkan oleh sifat dari resin akrilik yang dapat menyerap air sehingga mengakibatkan ekspansi dari akrilik tersebut. ${ }^{9}$ Pada penelitian ini digunakan air sebagai media dari larutan ekstrak bunga sepatu yang dapat menjadi salah satu faktor penyebab timbulnya kekasaran pada permukaan akrilik. Permukaan resin akrilik yang kurang rata dapat menjadi faktor retensi bagi $C$. albicans. $^{23}$

Hasil pada kelompok perlakuan ekstrak bunga sepatu konsentrasi $75 \%$ menunjukkan jumlah koloni $C$. albicans terendah dibandingkan kelompok perlakuan ekstrak bunga sepatu konsentrasi $62,5 \%$. Hal ini menunjukkan semakin tinggi konsentrasi ekstrak bunga kembang sepatu, maka jumlah koloni $C$. albicans yang tumbuh akan semakin rendah. ${ }^{22,24}$ Selain itu, kandungan dari bunga sepatu mampu menghambat pertumbuhan $C$. albicans. Bunga sepatu mengandung berbagai macam senyawa di dalamnya antara lain flavonoid, tannin, saponin, anthocyanin. ${ }^{25}$

Kandungan dalam bunga sepatu yang memiliki senyawa antifungi ialah flavonoid dari golongan quercetin yang dapat menghambat pertumbuhan pada jalur biosintesis ergosterol $C$. albicans. Senyawa ini melekat pada ergosterol yang merupakan komponen utama dari $C$. albicans dan membentuk transmembrane ion channel yang kemudian menyebabkan peningkatan permeabilitas membran yang menyebabkan kebocoran 
kandungan intrasel. Sebagai hasilnya ialah terjadi pembentukan membran plasma dengan ketidakutuhan struktural dan fungsional sehingga terjadi perubahan fungsi membran plasma $C$. albicans. ${ }^{22,26}$ Selain quercetin, terdapat senyawa cyanidin dari golongan anthocyanin yang dapat menghambat pertumbuhan C. albicans. Mekanisme kerja dari cyanidin yaitu dapat merusak dinding sel $C$. albicans dengan cara menghambat enzim $\beta(1,3)$-D-glucan synthase sehingga dapat memblokir sintesis $\beta(1,3)$ glucan yang berfungsi mengontrol aktvitas enzim untuk viabilitas sel. ${ }^{22}$ Pada penelitian ini, pertumbuhan $C$. albicans tidak terhambat sepenuhnya pada resin akrilik yang direndam dalam larutan ekstrak bunga sepatu $75 \%$. Hal ini tidak sejalan dengan penelitian yang dilakukan Krista dan Arundina $^{22}$ yang mendapatkan bahwa ekstrak bunga sepatu $75 \%$ telah mampu menghambat secara keseluruhan. Kemungkinan hal ini dapat dipengaruhi oleh perbedaan metode pengenceran dengan penelitian sebelumnya. Pada penelitian ini pengenceran dilakukan pada media akuades sedangkan pada penelitian sebelumnya pengenceran dilakukan dengan metode dilusi menggunakan media Sabaroud dextrose broth (SDB). Perbedaan pelarut dapat memengaruhi tingkat homogenitas larutan ekstrak bunga sepatu, yang juga dapat memengaruhi efektifitas kerja ekstrak bunga sepatu dalam menghambat pertumbuhan $C$. albicans. $^{22,27,28}$

Pada penelitian ini, pertumbuhan $C$. albicans terhambat sepenuhnya pada resin akrilik yang direndam dalam larutan sodium hipoklorit. Hal ini selaras dengan penelitian yang dilakukan oleh Ramírez-Verduzco et $\mathrm{al}^{27}$ yang melaporkan bahwa sodium hipoklorit dapat menghambat pertumbuhan $C$. albicans secara keseluruhan dan memiliki kemampuan untuk membersihkan permukaan akrilik serta mengendalikan pertumbuhan $C$. albicans karena memiliki kemampuan mekanik berupa penghambatan pembentukan biofilm pada permukaan akrilik.

Berdasarkan uji Mann-Whitney pada uji antar kelompok, didapatkan hasil bahwa perendaman ekstrak bunga sepatu $75 \%$ dengan sodium hipoklorit, ekstrak bunga sepatu $75 \%$ dengan akuades steril, ekstrak bunga sepatu $62,5 \%$ dengan sodium hipoklorit, ekstrak bunga sepatu $62,5 \%$ dengan akuades steril, dan sodium hipoklorit dengan akuades steril memiliki perbedaan bermakna $(\mathrm{p}<0,05)$. Hasil antara kelompok perendaman dalam ekstrak bunga sepatu $75 \%$ dan $62,5 \%$ tidak berbeda secara bermakna dengan nilai $\mathrm{p}=0,562(\mathrm{p}>0,05)$. Hal ini tidak sejalan dengan penelitian sebelumnya yang dilakukan oleh Krista dan Arundina $^{22}$ yang mendapatkan perbedaan bermakna pada kelompok perlakuan ekstrak bunga sepatu $62,5 \%$ dan $75 \%$. Faktor yang dapat memengaruhi hasil tersebut ialah perbedaan tingkat homogenitas antara kelompok ekstrak bunga sepatu 62,5\% dan $75 \%$. Tingkat homogenitas kedua kelompok perlakuan tersebut diamati secara visual, sehingga bersifat kurang objektif. ${ }^{29}$ Perbedaan rentang konsentrasi antar kelompok perlakuan I dan II yang cukup sempit dapat menjadi penyebab kurang bermaknanya perbedaan jumlah koloni $C$. albicans antara keduanya, sehingga perbedaan aktivitas antifungal tidak bermakna, walaupun semakin tinggi konsentrasi ekstrak bunga sepatu maka semakin tinggi efektivitasnya. Hal ini dapat disebabkan karena ekstrak bunga sepatu dengan konsentrasi $62,5 \%$ merupakan konsentrasi terkecil dalam menghambat pertumbuhan $C$. albicans. ${ }^{30}$

Tingkat homogenitas dalam pengenceran dapat memengaruhi distribusi konsentrasi yang secara tidak langsung dapat berpengaruh pada efektivitas kerja larutan dalam menghambat pertumbuhan mikroorganisme. ${ }^{29}$ Selain itu, prosedur pada penelitian ini tidak dilakukan dalam alat pensteril udara seperti laminar air flow yang dapat juga memengaruhi hasil dari pertumbuhan C. albicans. ${ }^{31}$ Walaupun kedua kelompok perlakuan tersebut tidak memiliki perbedaan bermakna namun tetap berpengaruh pada pertumbuhan koloni $C$. albicans karena terdapat perbedaan bermakna antara kelompok perlakuan tersebut dengan kelompok kontrol negatif dan positif. Hal ini menandakan bahwa terdapat pengaruh perendaman ekstrak bunga sepatu (H. rosa sinensis L.) 
terhadap pertumbuhan $C$. albicans pada plat resin akrilik. Simpulan tersebut dibuktikan dengan jumlah koloni $C$. albicans pada kelompok yang direndam dalam ekstrak bunga sepatu $75 \%$ dan $62,5 \%$ lebih rendah secara bermakna dibandingkan kelompok kontrol negatif yang direndam dalam akuades. Kandungan quercetin pada bunga sepatu dapat menghambat pertumbuhan $C$. albicans dengan cara meningkatkan permeabilitas membran sehingga menyebabkan kebocoran kandungan intrasel dari $C$. albicans. $^{22,26}$

\section{SIMPULAN}

Perendaman ekstrak bunga sepatu $(H$. rosa sinensis L.) berpengaruh terhadap pertumbuhan $C$. albicans pada plat resin akrilik.

\section{Konflik Kepentingan}

Penulis menyatakan tidak terdapat konflik kepentingan dalam studi ini.

\section{Ucapan Terimakasih}

Ucapan terimakasih disampaikan kepada semua pihak yang terlibat dalam penelitian ini di Laboratorium Mikrobiologi Fakultas Kedokteran Universitas Diponegoro, Semarang, sehingga hasil penelitian ini dapat dituangkan dalam bentuk artikel ilmiah ini

\section{DAFTAR PUSTAKA}

1. Siagian KV. Kehilangan sebagian gigi pada rongga mulut. e-CliniC. 2016;4(1):1-6.

2. Kemenkes RI. Riset Kesehatan Dasar Tahun 2018. Jakarta: Kementrian Kesehatan Republik Indonesia, 2018.

3. Budiono, Endang S, Diyah F. Pengembangan instrumen penilaian kinerja keterampilan mencetak rahang bergigi teknik mukostatik. J Res Educ Res Eval. 2016; 5(1):49-56.

4. Song YG, Lee SH. Efficacy of newly developed denture cleaning device on physical properties of denture material and Candida biofilm. J Dent Sci. 2019; 14(3):248-54.

5. Driscoll CF, Freilich MA, Guckes AD, Knoernschild KL, Mcgarry TJ. The Glossary of Prosthodontic Terms (9th ed). J Prosthet Dent. 2017;117(5):1-105.
6. Rifdayanti GU, Firdaus IWAK, Sukmana BI. Pengaruh perendaman ekstrak batang pisang mauli $25 \%$ dan daun kemangi $12,5 \%$ terhadap nilai kekasaran permukaan basis akrilik menggunakan resin akrilik tipe heat cured. DENTIN. 2019;3(3):75-81.

7. Onwubu SC, Mdluli PS, Singh S. The effect of colloidal silica and diamond suspensions on the surface roughness of automatically finished heat-polymerized acrylic resin. J Prosthet Dent. 2018; 120(3):485-90.

8. Catur SS, Silalahi PR, Mertisia I. Prosedur pembuatan gigi tiruan sebagian lepasan akrilik pada gigi 2 untuk menggantikan gigi tiruan sebagian nonformal. J Anal Kesehat. 2018;6(2):611-5.

9. Sofya PA, Rahmayani L, Fatmawati F. Tingkat kebersihan gigi tiruan sebagian lepasan resin akrilik ditinjau dari frekuensi dan metode pembersihan. J Syiah Kuala Dent Soc. 2016;1(1):91-5.

10. Aditama AP, Sunarintyas S, Widjijono W. Pengaruh jenis dan volumetrik fiber terhadap kekuatan transversal reparasi plat resin akrilik. Maj Kedokt Gigi Indonesia. 2015;1(1):102-8.

11. Stumpel LJ. In-Office Fabrication of a definitive cast and duplication of an interim implant-supported fixed acrylic resin complete denture. J Prosthet Dent. 2017;118(2):135-9.

12. Newman M, Takei H, Klokkevold P, Carranza F. Newman and Carranza's Clinical Periodontology. (13th ed). Philadelphia: Elsevier, 2018.

13. Davoudi A, Ebadian B, Nosouhian S. Role of laser or photodynamic therapy in treatment of denture stomatitis: a systematic review. J Prosthet Dent. 2018;120(4):498-505.

14. Junaedi DR, Salim S, Soekobagiono. Efektivitas ekstrak daun senggani (Melastoma candidum D. Don) dalam menghambat pertumbuhan Candida albicans pada resin akrilik heat cured. J Prosthodont. 2013;4(1):8-13.

15. Cover TM, Gacs P, Gray RM. Kolmogorov's contributions to information theory and algorithmic complexity. Ann Probab. 1989;17(3):840-65.

16. Axe AS, Varghese R, Bosma M, Kitson N, Bradshaw DJ. Dental health professional recommendation and consumer 
habits in denture cleansing. J Prosthet Dent. 2016;115(2):183-8.

17. Ningsih DS, Rahmayani L, Bomazdicahyo P. Pengaruh durasi perendaman resin akrilik heat cured dalam larutan sodium hiprokolorit $0,5 \%$ terhadap perubahan dimensi. Cakradonya Dent J. 2013;5(2): 542-618.

18. Tukiran, Suyatno, Hidayati N. Skrining fitokimia pada beberapa ekstrak dari tumbuhan bugenvil (Bougainvillea glabra), bunga sepatu (Hibiscus rosasinensis L.), dan daun ungu (Graptophylum pictum Griff.). Pros Semin Nas Kim. 2014:235-44.

19. Vastrad VJ, Byadgi AS. Phytochemical screening and antibacterial activity of Hibiscus rosa - sinensis leaf extracts. Int J Curr Microbiol Appl Sci. 2018;7(3): 3329-37.

20. Shen HM, Chen C, Jiang JY, Zheng YL, Cai WF, Wang B, et al. The N-butyl alcohol extract from Hibiscus Rosa-Sinensis L. flowers enhances healing potential on rat excisional wounds. J Ethnopharmacol. 2017;198:291-301.

21. Silalahi M, Nisyawati. The ethnobotanical study of edible and medicinal plants in the home garden of Batak Karo SubEthnic in North Sumatra, Indonesia. Biodiversitas. 2018;19(1):229-38.

22. Krista DPI, Arundina I, Istiati Potensi anti jamur ekstrak bunga kembang sepatu terhadap Candida albicans. Denta J. 2014;8(2):198-206.

23. Mozartha M, Wahyuningsih Rais S, Purba R, Ramadhanti J. The potency of daun dewa extract as a growth inhibitor of $C$. Albicans on acrylic resin plate. Potensi ekstrak daun dewa sebagai penghambat pertumbuhan $C$ Albicans pada lempeng resin akrilik. Makassar Dent J. 2019; 8(1):1-5.

24. Zulkarnain M, Safitri E. Pengaruh perendaman basis gigi tiruan resin akrilik polimerisasi panas dalam klorheksidin dan ekstrak bunga Rosella terhadap Jumlah Candida albicans. Dentika Dent J. 2016;
19(2):110-6.

25. Samsudin, R. Bioaktifitas bunga sepatu (Hibiscus Rosa-Sinensis L.) terhadap kadar kolesterol darah mencit (mus musculus) yang mengalami hiperkolesterolemia dengan diet tinggi lemak. The Journal of Muhamadiyah Medical Laboratory Technologist. 2017;2(1):8994.

26. Vijayakumar S, Morvin Yabesh JE, Arulmozhi P, Praseetha PK. Identification and isolation of antimicrobial compounds from the flower extract of Hibiscus rosa-sinensis $L$ : in silico and in vitro approaches. Microb Pathog J. 2018;123:527-35.

27. Ramírez-Verduzco LF, De Los Reyes JA, Torres-García E. Solvent effect in homogeneous and heterogeneous reactions to remove dibenzothiophene by an oxidation-extraction scheme. Ind Eng Chem Res. 2008;47(15):5353-61.

28. Khan N, Hashmi MS, Khan SU, Chaudhry F, Tlili I, Shadloo MS, et al. Effects of homogeneous and heterogeneous chemical features on oldroyd-b fluid flow between stretching disks with velocity and temperature boundary assumptions. Math Probl Eng. 2020;1(1):1-13.

29. Pasquarella C, Sansebastiano GE, Ferretti S, Saccani E, Fanti M, Moscato U, et al. A mobile laminar airflow unit to reduce air bacterial contamination at surgical area in a conventionally ventilated operating theatre. J Hosp Infect. 2007;66(4):313-9.

30. Prayitno YH. Uji aktivitas antifungal ekstrak metanol mentah rimpang jeringau merah (Acorus calamus Linn.) terhadap pertumbuhan Malassezia furfur secara in vitro [Naskah Publikasi]. Pontianak: Univ Tanjungpura; 2015.

31. Iwasaki M, Kanda J, Hishizawa M, Kitano T, Kondo T, Yamashita K, et al. Effect of laminar air flow and building construction on aspergillosis in acute leukemia patients: a retrospective cohort study. BMC Infect Dis. 2019;19(1):1-9. 